\title{
Does Mind Mapping Technique Affect Creative Thinking Skill and Cognitive Learning Outcomes?
}

\author{
Nur Eka Kusuma Hindrasti ${ }^{1}$, Nolis Febry Anggraini ${ }^{2}$, Trisna Amelia ${ }^{3}$ \\ \{nurekakh2017@umrah.ac.id ${ }^{1}$, nolisfa@gmail.com², trisna.amelia@umrah.ac.id ${ }^{3}$ \} \\ 1,2,3Biology Education Department, University of Maritim Raja Ali Haji, Jl. Politeknik, \\ Senggarang Tanjungpinang 29115 Indonesia
}

\begin{abstract}
Education in Indonesia is gradually shifting from being oriented towards cognitive learning outcomes to 21 st-century skills. Therefore, this study investigated the ability of the mind mapping techniques to affect students' creativity and cognitive learning outcomes. This pre-experimental study employed an intact-group comparison design with data collected from 68 eighth-grade students of SMP Negeri 5 Tanjungpinang. The students were selected for experimental and control groups based on the homogeneity and normality tests results. The instrument used to measure their creativity, and cognitive learning outcomes were easy and in multiple-choice tests. The result showed that the mind mapping technique has no effect on creativity but affects cognitive learning outcomes. Meanwhile, its simultaneous implementation affects both learning outcomes.
\end{abstract}

Keywords: Cognitive Learning Outcomes; Creativity; Human Respiratory System Subjects; Mind Mapping.

\section{Introduction}

Although creative thinking has long been a concern for teachers, it starts to be prioritized by students in this 21st century [1]. According to Ramadhan, the teacher is one of the main factors that support the growth and development of students' knowledge and skills. Therefore, they do not just carry out learning as part of their routine work, rather they act as role models [2]. Young peoples' creative abilities are most likely to be developed in an atmosphere where the teachers are properly engaged [3]. Creativity is characterized by the ability to perceive the world from a different perspective, make connections between seemingly unrelated phenomena, and generate solutions [4]. Creativity skills enable students to develop, implement, and convey new ideas to others while being open and responsive to new and different perspectives. Both students and teachers need to apply this skill in their learning process, especially with the complex challenges associated with the 21 st century.

Although educators claim to value creativity, they do not always prioritize its usage while teaching in the classroom [5]. Some researchers used the term 'creativity gap' to describe the inconsistency between its perceived value and committed usage. Several educators do not prioritize the creativity possessed by their students, despite agreeing to the need for them to be creative in a classroom or environment learning. This skill is limited to certain contexts, such as painting on Learning Arts and Culture, which is unfortunate because creativity does not only cover art. When the creativity of students is low, the potential for development in the cognitive realm becomes narrow, thereby decreasing the learning outcomes. Therefore, it can be concluded that creativity is needed for students to easily understand difficult lessons with 
adequate information capable of broadening their knowledge. Teachers as decision-makers need to be able to choose and determine appropriate strategies, models, methods, and learning techniques in delivering material to ensure students achieve the right learning outcomes.

One of the learning techniques that can be applied to understand better the use of mapping techniques is creativity. According to [6], this process is effective and requires a lot of writing or note-taking activities [6]. In mind mapping, the theme is written in the central part to ensure other related- ideas are emitted. Hence, it is easy for someone who applies mind mapping to focus on the main ideas to understand better the information collected. Mind mapping is a tool used to make even the most boring task fun and interesting, thereby improving concentration and recall while promoting the flow of thoughts more smoothly. Furthermore, it increases creativity and enhances one's ability to remember [7]. Mind mapping learning technique is applied to improve students' memory, creativity, and ability to understand a concept.

During the initial observation process at SMP Negeri 5 Tanjungpinang, the result represented that the students' creativity was quite good. However, this was not fully visualized in the science learning process, as indicated when students were asked to mention examples of monocot and dicot plants during a quiz on Plant Structure and Tissue material. Some were only able to give general examples such as those in books even though many types of plants in their school environment can be mentioned. The low variety of answers signifies a decrease in the creativity and fluency section. When the group was tasked with making a wall magazine (mading) on Simple Aircraft material, some only displayed pictures of simple planes and their formulas, leaving a space filled with unrelated decorations. This is quite unfortunate, considering that they can insert the meaning and function of each simple machine in the unused part. The low quality of the variety of answers provided by students in the making process illustrates their low creativity in the flexibility section.

The interview results with 3 of the 4 science subject teachers at SMP Negeri 5 Tanjungpinang, show that (1) The common difficulties encountered by teachers in class are when students become passive fail to focus on the learning process. (2) The three teachers interviewed had no knowledge of mapping, (3) The method that is often used in learning is the discussion and assignment with learning techniques in the form of memorization. (4) Students' learning outcomes are lacking in the material that contains physics and quite good in those containing biology. (5) Student creativity is sufficient, but only a few are active and have not seen it thoroughly in science subjects. Finally, (6) the learning outcomes of superior and regular class students have completeness of almost $75 \%$ and $62-70 \%$, with a minimum completeness criterion value (KKM) of 73 in junior high school.

This research is based on several relevant sources, including preliminary studies conducted by [8], [9], [10], [11], and [12], which show a positive influence from the use of mind mapping. This research aims to determine the effect of applying mind mapping techniques on the creativity, cognition, and outcomes of class VIII students on the respiratory system material at SMP Negeri 5 Tanjungpinang in the 2020/2021 academic year.

\section{Method}

This is a pre-experimental study with an intact-group comparison design used to investigate the mind mapping techniques affecting students' creative thinking skills and cognitive learning outcomes. The sample population is the 220 students from 6 classes in the eighth grade at SMPN 5 Tanjungpinang. From the sample, data were collected from 68 students equally assigned to 
the experimental and control groups. The classes selection was based on the result of the equality test containing multiple choice questions on the materials studied by the students. The experimental (X) and control (C) groups were taught mind mapping and summarizing techniques. The research design carried out in this study, which was conducted from August to November 2020, is shown in Figure 1.

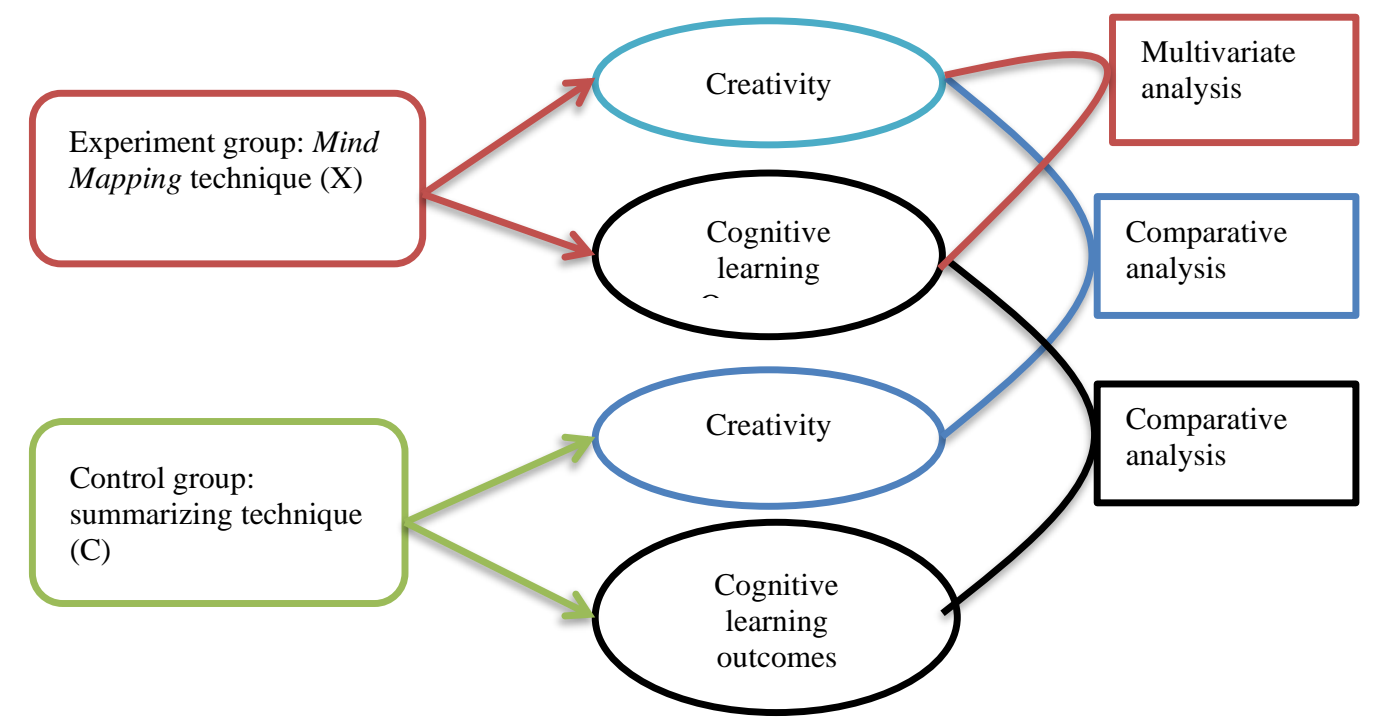

Fig. 1: Research design

The independent variable of this study is the students' creative thinking skills measured using seven essay questions. The instrument was developed by first making a grid that refers to the indicators fluency, flexibility, originality, and elaboration [13]. The creative thinking assessment was performed using a rubric. Furthermore, test instruments were used to obtain data on students' cognitive learning outcomes through the provision of posttests with 20 multiple-choice questions. The questionnaire instrument was used to obtain student response data from the experimental class regarding the application of mind mapping techniques.

Data collected were grouped into creativity and cognitive learning outcomes and further processed using Ms. Excel 2010 and SPSS 24.0. Furthermore, the data collected were analyzed using comparative and multivariate analysis to determine whether or not there is a significant difference in the sample mean of the two variables. The comparative and multivariate analysis performed Normality, Homogeneity, Hypothesis and F-MANOVA Tests using Kolmogorov Smirnov, Lavene, Independent Sample T-Tests, and multivariate analysis.

\section{Result and Discussion}

\subsection{Result}

\subsubsection{Students' Creativity thinking skills}

According to Guilford [14], creativity in this research covers aspects of fluency, flexibility, originality dan elaboration. The results is represented in Table 1. 
Table 1: Recapitulation of the results of the creativity assessment in the two groups

\begin{tabular}{|c|c|c|c|c|}
\hline \multirow[t]{2}{*}{ Creativity aspect } & \multicolumn{2}{|c|}{$\begin{array}{l}\text { Experiment group }(X) \\
\text { mind mapping technique }\end{array}$} & \multicolumn{2}{|c|}{$\begin{array}{l}\text { Control group }(C) \\
\text { summarizing technique }\end{array}$} \\
\hline & Tes ke-1 & Tes ke-2 & Tes ke-1 & Tes ke-2 \\
\hline Fluency & 54.3 (Good) & 55.3 (Good) & 53.3 (Good) & 53 (Good) \\
\hline Flexibility & 54 (Good) & 56 (Good) & 53 (Good) & 55 (Good) \\
\hline Originality & 53 (Good) & 56 (Good) & 51 (Good) & 45 (Good) \\
\hline Elaboration & 49 (Good) & 47.5 (Good) & 45 (Good) & 44 (Good) \\
\hline Average (\%) & 48.25 (Good) & & 44.5 (Good) & \\
\hline $\begin{array}{l}\text { Average creativity } \\
\text { score }\end{array}$ & 79.5151 & & 76.441 & \\
\hline
\end{tabular}

Table 1 shows that students' creativity in each group is good, with average creativity greater in the experimental group by $48.25 \%$ compared to the control $(44.5 \%)$.

\subsubsection{Cognitive Learning Outcomes}

Learning is carried out online through Google Classroom using mind mapping and notetaking techniques in the experimental and control groups. The next step is to give a post-test to determine students' cognitive abilities from the two groups. The questions given are compiled based on the cognitive aspects of Revised Bloom's Taxonomy and validated by expert lecturers. The minimum completeness criteria value (KKM) of students in science lessons at SMP Negeri 5 Tanjungpinang is 73. Meanwhile, their classical mastery diagram and the average learning outcomes in both groups are shown in Table 2.

Table 2: Comparison of cognitive learning outcomes data in the two groups

\begin{tabular}{|c|c|c|c|c|c|}
\hline \multirow{2}{*}{ Group } & \multicolumn{3}{|c|}{ The result of cognitive aspect (\%) } & \multirow{2}{*}{$\begin{array}{l}\text { The learning } \\
\text { outcomes }\end{array}$} & \multirow{2}{*}{$\begin{array}{l}\text { Classical } \\
\text { completeness (\%) }\end{array}$} \\
\hline & C3 & C4 & C5 & & \\
\hline Experiment $(\mathrm{X})$ & 91 & 97 & 94 & 87,65 & 94 \\
\hline Control (C) & 82 & 76 & 85 & 80,44 & 79 \\
\hline
\end{tabular}

Based on Table 2, it is known that the difference in the results of the percentage of cognitive aspects that include the abilities of $\mathrm{C} 3, \mathrm{C} 4$, and $\mathrm{C} 5$ is greater for students in the experimental group than those in the control group.

\subsubsection{Students response}

Questionnaires were given to 34 students in the experimental group (X) to determine their response to mind mapping techniques in the implemented learning process. The questionnaire was distributed online due to the current situation of the Covid-19 pandemic, while their response is shown in Table 3. 
Table 3: Student response to the implementation of mind mapping techniques

\begin{tabular}{|c|c|c|c|}
\hline Aspect & No & Questionnaire statement & $\begin{array}{l}\text { Questionnaire } \\
\text { interpretation } \\
(\%)\end{array}$ \\
\hline \multirow{2}{*}{$\begin{array}{l}\text { The feeling } \\
\text { when making a } \\
\text { mind mapping }\end{array}$} & 1 & $\begin{array}{l}\text { I feel happy and excited when assigned to create a } \\
\text { Mind Mapping }\end{array}$ & 74.2 \\
\hline & 2 & $\begin{array}{l}\text { I became confused when the teacher gave the task to } \\
\text { make a Mind Mapping }\end{array}$ & 58.8 \\
\hline \multirow[t]{2}{*}{$\begin{array}{l}\text { Clarity of } \\
\text { assignment }\end{array}$} & 3 & $\begin{array}{l}\text { I find it difficult to make Mind Maps because I don't } \\
\text { know what it is }\end{array}$ & 57.3 \\
\hline & 4 & $\begin{array}{l}\text { I prefer only to be asked to take notes by summarizing } \\
\text { rather than making a Mind Map }\end{array}$ & 50.7 \\
\hline \multirow{2}{*}{$\begin{array}{l}\text { Easy to } \\
\text { understand } \\
\text { lessons }\end{array}$} & 5 & $\begin{array}{l}\text { I find it easy to remember the subject matter if I make a } \\
\text { Mind Map }\end{array}$ & 73.5 \\
\hline & 6 & $\begin{array}{l}\text { I find it difficult to understand the concept of material } \\
\text { when making a Mind Map }\end{array}$ & 52.2 \\
\hline \multirow[t]{2}{*}{$\begin{array}{l}\text { Cultivation of } \\
\text { creativity }\end{array}$} & 7 & $\begin{array}{l}\text { I am able to generate creative ideas when making Mind } \\
\text { Maps }\end{array}$ & 76.4 \\
\hline & 8 & $\begin{array}{l}\text { I feel the need to find additional information to explore } \\
\text { ideas when creating a Mind Map }\end{array}$ & 77.2 \\
\hline \multicolumn{3}{|c|}{ Overall interpretation } & $65 \%($ Good $)$ \\
\hline
\end{tabular}

Table 3 shows that the lowest percentage of questionnaire interpretation is found in the 4th questionnaire item at $50.7 \%$, with the statement "I prefer being asked to take notes by summarizing rather than making a mind map." This indicates that students feel happier taking notes on how to summarize compared to making a mind map. Furthermore, the highest percentage of questionnaire interpretation is in the 8 th item at $77.2 \%$, with the statement "I feel the need to find additional information to explore ideas when making mind maps." This shows that students need to find additional information to explore their ideas in taking notes with mind mapping techniques. Overall, though the results of the total percentage of the questionnaire are $65 \%$, it can be concluded that students respond well to the application of mind mapping techniques in their learning.

\subsubsection{Mind Mapping}

This data was obtained by observing the instrument used to determine the quality of students' mind mapping in the experimental group. It consists of 5 assessment aspect, namely Structure, Explanatory, Communication, Connection between the sections, and Extent of coverage. The results of the mind mapping assessment are shown in Table 4.

Table 4: Mind Mapping assessment results

\begin{tabular}{lll}
\hline Mind mapping aspect & Score $(\boldsymbol{\%})$ & Criteria \\
\hline Structure & 63 & Good \\
Explanatory & 70.30 & Good \\
Communication & 60 & Good \\
Connection between sections & 66 & Good \\
Extent of coverage & 60 & Good \\
\hline Overall value of mind mapping & $\mathbf{6 5}$ & Good \\
\hline
\end{tabular}




\subsection{Discussion}

Several factors are used to describe the data obtained from the research results. First, the acquisition of the average value of creativity in each experimental and control group is 79.515 and 76.441, with a significance value of 0.270 ( $\mathrm{Sig}$. > 0, 05) showed no difference in using the mind mapping technique. It can be concluded that students' creativity in both groups is at the same level, while those from the experimental group have more potential for good creativity. Hennessey \& Amabile stated that a person's creative potential can be developed based on internal and external supporting factors in the form of openness to sources of information or ability to assess and select thoughts without being influenced by criticism or praise from others and the level of cognitive abilities and conditions of the social environment [14]. From the process, it was known that through student response questionnaires in the experimental group, those that used the mind mapping techniques felt the need to look for additional information from books or internet sources. Meanwhile, the learning process carried out by students in the control group using the summarizing technique indicated their need for relevant information to the topic of the summary and need to evaluate the sources of information and ideas generated through their thoughts to be able to put together the main ideas which are then written down properly. Kaufman and Baghetto grouped the level of creativity into 4 categories, and from the comparative results possessed by students in both groups, the fourth category, namely Mini-C Creativity, is based on experience, action, or events that occur when the individual shows flexibility, intelligence, and novelty in thinking by generating ideas [15].

After knowing their creativity level, the next step is to see how the criteria for student creativity are based on the 4P dimensions described by Rhodes [16], namely Person, Process, Product, and Press through the fulfillment of the creativity aspect proposed by [13], namely Flexibility, Fluency, Originality, dan Elaboration. Person criteria are determined by observing students' habits and thoughts in showing their interest in a problem by questioning or expressing their opinion. This shows the character is always curious and able to think critically through the things asked or the opinions conveyed. The fulfillment of the creativity aspect is in the form of the quantity of fluency to produce a variety of questions or opinions on a problem and the quality of the flexibility of questions. Process and Product criteria are identified through the Originality and Elaboration creativity in determining the authenticity of the opinions raised by students based on their critical thinking and analysis explained in detail. Then the Press criteria are analyzed from the influence of the environmental conditions of learners or students. This is in accordance with Hurlock, environmental conditions that can be in the form of the time needed to explore ideas, the opportunity to develop imagination and thinking, motivation to be creative, supportive means, and self-confidence and independence due to good interpersonal relationships [17].

The existence of a significant influence on the application of mind mapping techniques to students' cognitive learning outcomes is shown by the hypothesis testing results using the Independent Sample T-Test with a Sig value of 0.002. This indicates the Sig. $<0.05$, and the mean value of cognitive learning outcomes in the experimental and control groups are 87.647 and 80.441. Therefore, the comparative analysis results on hypothesis testing are accepted with a significant effect on mind mapping application to students' cognitive learning outcomes. The benefits of mind mapping proposed by DePorter, which stated that making mind mapping help students in compiling information will be more patterned and visually directed to help them record or store information, strengthen understanding, and easily recall activities [18]. This also strengthens Buzan's statement that when individuals make a mind mapping, there will be a connection between the newly received information obtained, thereby resulting in a new and 
different mind mapping process. According to Supratik, each student's learning outcomes differ in accordance with their experiences, abilities, acquisition, and skills [19].

The research conducted on applying mind mapping techniques to student creativity is also in line with preliminary studies. Examples are the research conducted by Rumanti, which showed a significant difference in the cognitive learning outcomes of the experimental and control groups that applied mind maps and lectures as well as questions and answers [8]. Subsequently, the research conducted by Tantowi showed that there are differences in student learning outcomes tests between the experimental and the control classes, thereby producing an effect of the application of mind mapping techniques on students' mathematics learning outcomes [10]. Meanwhile, Zahra's research shows the influence of mind mapping learning methods on students' Fiqh outcomes [11].

The acquisition of $\mathrm{F}$ and significant -values of 3.575 and 0.040 (Sig. > 0.05) indicates and influences mind mapping techniques' application to creativity and student cognitive learning outcomes. The average value of the group of students that applied the mind mapping technique showed better results than those that used the summarizing technique. However, in terms of creativity, the difference was not significant, while in learning outcomes, the group in the experimental group gained new knowledge and skills regarding note-taking techniques. Cognitive learning outcomes obtained from the posttest in the experimental group showed that students' abilities in cognitive aspects of $\mathrm{C} 3, \mathrm{C} 4$, and C5 were in very good interpretation. This research is in line with the preliminary studies regarding the effect of using mind mapping on creativity and student cognitive learning outcomes. Examples include the research conducted by Zahra showing the influence of mind mapping learning methods on creativity and students' Fiqh learning outcomes [11]. The implementation of the mind mapping model with scattergories game can also improve creativity and learning outcomes in national education materials [20]. In economic subject, the mapping learning model can improve students' creativity and learning outcomes [21].

\section{Conclusion}

Based on the research conducted, the following conclusions were drawn. First, the average value of the creativity of the experimental group is better (79.515) than the control group (76.441). However, the significance value (Sig. $0.270>0.05$ ) shows no difference, therefore the application of mind mapping techniques does not affect the creativity of class VIII students on the material of the human respiratory system. Second, the average value of cognitive learning outcomes of experimental group is better (87.647) than the control (80.441). Also, the significance value (Sig. $0.002<0.05)$ shows a difference, therefore the application of mind mapping techniques has an effect on the results. Third, the acquisition of an F-score of 3.575 and a significance value (Sig. $0.040<0.05$ ) indicates that the application of mind mapping techniques has a significant effect on creativity and cognitive learning outcomes of class VIII students on the human respiratory system material.

\section{References}

[1] Irwan, F., Zubaidah, S., Sulisetijono, \& Astriani, M: Does remap-STAD have the potential to promote students' creative thinking skills?. AIP Conference Proceedings. pp. 1-7 (2021)

[2] Raadhana, F.: The Relationship between pedagogic competence and teacher creativity. Thesis of University of Islam Negeri Syarif Hidayatullah, Jakarta (2016) 
[3] Jeffrey, B. \& Craft, A.: Teaching creatively and teaching for creativity: Distinctions and Relationships. Education Studies, pp. 77-78 (2004)

[4] Sirohi, A.: Development of creativity through English teaching in the students at secondary level a study. Thesis of Banasthali University (2016)

[5] Gabora, L.: What Creativity Really Is and Why School Needs It. The Conversation. Retrieved from https://theconversation.com/what-creativity-really-is-and-why-school-needs-it-81889 (2017)

[6] The University of Adelaide: Mind mapping writing centre learning guide. The University of Adelaide Writing Centre. Retrieved from https://www.adelaide.edu.au/writingcentre/sites/default/files/docs/learningguide-mindmapping.pdf (2014)

[7] Zemptakis, L. A., \& Trisonis, L.: Creativity development in engineering education: the case of mind mapping. Journal of Management Development. pp 370-380 (2007)

[8] Rumanti, N.,D.: The effect of the application of mind maps on cognitive learning outcomes of natural science in grade IV students. Thesis of University of Negari Yogyakarta (2014)

[9] Aprilia, R., \& Manurung, S.: The effect of mind mapping techniques on students' writing skills. Dimensi. pp. 176-185 (2019)

[10] Tantowi, Y.. The effect of mind mapping techniques on motivation and learning outcomes of mathematics on trigonometry material for students of class X man 3 Tulungagung in the 2018/2019 school year. Thesis of Institut of Islam Negeri Tulungagung (2019)

[11] Zahro, F, F.: The effect of the mind mapping method on creativity and student learning outcomes at MI Darussalam, Komayan Wonodadi, Blitar. Thesis of Institut of Agama Islam Negeri Tulungagung (2019)

[12] Acesta, A. The effect of the application of the mind mapping method on students' creative thinking skills. NATURALISTIC : Jurnal Kajian Penelitian Pendidikan dan Pembelajaran, pp.581-586 (2020).

[13] Guilford, J. P.: Characteristics of creativity. ERIC Document Reproduction Service No. ED 080171. Retrieved from https://files.eric.ed.gov/fulltext/ED080171.pdf, (2019).

[14] Gerrig, R. J., \& Zimbardo, P. G.: Psychology and life. Allyn and Bacon. (2013)

[15] Cambridge Assessment International Education: Innovation and creativity. In Developing the Cambridge Learner Attributes (p. 55). Cambridge Assessment International Education. Pp. 53-74 (2011)

[16] Min, T., \& Gruszka, A. (2017). The 4P' s Creativity Model and its Application in Different Fields. In Handbook of the Management of Creativity and Innovation. (Chapter 3). World Scientific Press, p51-71

[17] Rohani: Improving the creativity of early childhood through the media of used materials. Raudhah, 5(2). (2017)

[18] DePorter, B.: Quantum teaching. Google Books. pp. 227 (2000)

[19] Widodo, L. W.: Improving learning activities and student learning outcomes with the problem based learning method in class VIIA MTs Negeri Donomulyo Kulon Progo in the 2012/2013 school year. Jurnal Fisika Indonesia, pp. 32-35 (2014)

[20] Pudjiastuti, S. R.: The implementation of the mind mapping model with scattergories game also can improved creativity and learning outcome, but in national education materials [20]. Journal of Humanities and Social Studies, pp. 22-24 (2018)

[21] Kulsum, N., U.: Mind mapping model in increasing students' creativity and learning outcomes. Classroom Action Research Journal, pp. 127-132 (2018) 